\title{
Adaptation Strategy on Urban Air Quality, Case Study: Semarang Urban Area, Indonesia
}

\author{
Evi Gravitiani*, Rosalina Enny Widi Kristanti \\ Faculty of Economics and Business, Sebelas Maret University, Indonesia
}

Copyright (C) 2015 Horizon Research Publishing All rights reserved.

\begin{abstract}
The economic growth in the urban areas is characterized by the growth of the industrial sector and traffic density. The increase in the amount of motorized vehicles caused an increase in emission in the air. Emission is mobile sources of pollution, which interfere with the air quality in the urban areas. These effects human health negatively. This research was estimating the willingness to pay (WTP) with the contingent valuation method. This research aims to determine the public awareness to keep their environment clean. It is indicated by people's WTP on policy implication that offered once every year. The strategy offered to diminish mobile sources of pollution are (1) improvement in transportation infrastructure, (2) reforestation, (3) replacement of old motorized vehicles, and (4) the use of alternative roads on traffic peak hours. The strategies to diminish the mobile sources of pollution were ranked by an Analytical Hierarchy Process (AHP) according to people's preference in the implementation. The strategies have implications in four consecutive years. The research result showed that the level of WTP of the society was still low, as only $38 \%$ of the people are willing to pay a maximum of 40,000 rupiah every year to reduce mobile pollution sources. The determinant factors of the WTP are estimated by the ordered probit method. The estimated results showed that the income of the respondents compared to health costs, caused by damaged lungs, eyes, and nose, has an influence on the WTP. While the age, education, and distance to the polluted area of the respondents are not significantly influencing the WTP.
\end{abstract}

Keywords Urban Air Quality, Willingness to Pay, Analytical Hierarchy Process

\section{Introduction}

Air pollution sources are mobile source and non-mobile source. Mobile source are motorize vehicles and sea transport. Non-mobile source are power station, industry and household. This paper focuses on motorized vehicle as a mobile source of air pollution.

The air pollutants are carbon monoxide (CO), Nitrogen
Oxide (NOx), Sulphure Oxide (SOx), Hidrocarbon (HC) and Particulate Matter (PM). They also give negative impact to human health (Meteorology Climathology and Geophysic Agency, 2012). These pollutants have different tresshold and government enactive them, it shown on table 1.

Table 1. Emission source and Tresshold enactived by government

\begin{tabular}{ccc}
\hline Pollutant & Source & Tresshold \\
\hline $\begin{array}{c}\text { Carbondioxide }(\mathrm{CO}) \\
\text { Sulphur diokside } \\
\left(\mathrm{SO}_{2}\right)\end{array}$ & $\begin{array}{c}\text { Mobile and } \\
\text { non-mobile source }\end{array}$ & $10 \mathrm{mg} / \mathrm{m}^{3}(9 \mathrm{ppm})$ \\
Particulate matter & Power station & $80 \mu \mathrm{g} / \mathrm{m}^{3}(0.03 \mathrm{ppm})$ \\
Mitrogen dioxide & non-mobile source & $150 \mu \mathrm{g} / \mathrm{m}^{3}:$ in 1 year \\
$\left(\mathrm{NO}_{2}\right)$ & Mobile and & $100 \mathrm{pg} / \mathrm{m}^{3}(0.05 \mathrm{ppm}):$ \\
Ozone $\left(\mathrm{O}_{3}\right)$ & non-mobile source & in 1 hour \\
& Formed in & $235 \mu \mathrm{g} / \mathrm{m}^{3}(0.12$ \\
atmosphere & $\mathrm{ppm}):$ in 1 year \\
\hline
\end{tabular}

Source: Meteorology Climathology and Geophysic Agency, 2012

In 2012, urban air quality evaluation indicates the decreasing of air quality in 44 cities in Indonesia, which are 14 metropolitant cities; 13 big cities; and 17 middle and small cities. Semarang, as a study area, is categorized in metropolitan cities. The indicators are city characteristic, commitment, and capacity. City characteristic are emission test, traffic performance, air quality, and fuel quality. Commintment and capacity include air quality monitoring, reducing, and also improving people awareness on air quality keeping.

Table 2. Amount of Motorized Vehicle on Semarang City

\begin{tabular}{cccc}
\hline \multirow{2}{*}{ Vehicle Type } & \multicolumn{3}{c}{ Year } \\
\cline { 2 - 4 } & (unit) & 2012 (unit) & 2013 (unit) \\
\hline Motocycle & 388,597 & 440,831 & 476,482 \\
Car & 1,697 & 96,044 & 100,827 \\
Box mobile & 37,501 & 38,109 & 39,063 \\
Bus & 1,697 & 1,586 & 1,442 \\
$*$ Public & 1,193 & 1,061 & 944 \\
transport & 504 & 525 & 498 \\
$*$ Private & 864 & 1,191 & 1,367 \\
Special Vehicle & 3,256 & 3,081 & 3,706 \\
Public transport & $\mathbf{3 8 2 , 4 2 8}$ & $\mathbf{6 2 4 , 3 2 9}$ \\
(exclude bus) & $\mathbf{4 3 5 , 3 0 9}$ & $\mathbf{5 8 9}$
\end{tabular}


Table 3. Air Quality Monitoring in Semarang City 2013

\begin{tabular}{cccccccc}
\hline \multirow{2}{*}{ No } & Air & Tresshold & \multicolumn{5}{c}{ Stations } \\
\cline { 4 - 8 } & Quality & $(\mathrm{ppm})$ & 1 & 2 & 3 & 4 & 5 \\
\hline 1 & $\mathrm{NO}_{2}$ & 316 & 187.2 & 54.8 & 215.1 & 189.4 & 183.2 \\
2 & $\mathrm{SO}_{2}$ & 623 & 0.162 & 0.012 & 0.082 & 0.099 & 0.141 \\
3 & Dust & 230 & 110 & 20.8 & 75 & 83.3 & 66.6 \\
4 & $\mathrm{~Pb}$ & 2 & 0.054 & 0.021 & 0.027 & 0.036 & 0.044 \\
5 & $\mathrm{CO}$ & 15,000 & 20,610 & 17,175 & $12,022.5$ & 6,870 & 153.43 \\
6 & $\mathrm{H}_{2} \mathrm{~S}$ & 0.02 & 0.00008 & 0.000055 & 0.000046 & 0.0001 & 0.00009 \\
7 & $\mathrm{NH}_{3}$ & 0.5 & 0.28 & 0.18 & 0.24 & & 0.16 \\
\hline
\end{tabular}

Source : Kariada, 2013

Table 4. Air Pollution Area from Mobile Source

\begin{tabular}{|c|c|c|c|c|c|}
\hline Area & Roads & Sub-district & $\begin{array}{c}\mathrm{CO} \mu \mathrm{g} / \\
\mathrm{m} 3\end{array}$ & Population & Samples \\
\hline $\begin{array}{l}\text { Bundaran } \\
\text { Kalibanteng }\end{array}$ & $\begin{array}{c}\text { Siliwangi } \\
\text { Martadinata } \\
\text { Jend.Sudirman } \\
\text { Pamularsih } \\
\text { A Rahman Saleh }\end{array}$ & $\begin{array}{c}\text { Semarang } \\
\text { Barat }\end{array}$ & 20,610 & 7.640 & 26 \\
\hline $\begin{array}{c}\text { Bundaran Tugu } \\
\text { Muda }\end{array}$ & $\begin{array}{c}\text { Jend. Sudirman } \\
\text { Pemuda } \\
\text { Pandanaran }\end{array}$ & $\begin{array}{l}\text { Semarang } \\
\text { Selatan }\end{array}$ & 17,175 & 8.316 & 26 \\
\hline
\end{tabular}

Source: Secondary data, 2013

\section{Transportation and Air Quality}

Semarang City is capital of Central Java Province, as a central of administration, industry, and, trade. In consequency, it insists the people have more economic activities than other city. People movement influences to increase of the amount motorized vehicle, it shown on table 2.

Air quality in Semarang city is indicated by some indicators, such as nitrogen dioxside $\left(\mathrm{NO}_{2}\right)$, Sulphure dioxside $\left(\mathrm{SO}_{2}\right)$, dust, lead $(\mathrm{Pb})$, carbon monoxide $(\mathrm{CO})$, hidro sulphure $\left(\mathrm{H}_{2} \mathrm{~S}\right)$, nitrogen $\left(\mathrm{NH}_{3}\right)$. Table 3 shows monitoring of air quality in Semarang City. It is done in five monitoring stations: Bundaran Kalibanteng station, Bundaran Tugu Muda station, Brigjend Katamso station, Kaligawe station, and Setiabudi station.

Carbon monoxide is above the tresshold in station 1 (Bundaran Kalibanteng) and station 2 (Bundaran Tugu Muda). Other poluttants are still below the tresshold. Bundaran Tugu Muda is central of government and traffic jam happen frequently. Bundaran Kalibanteng is crowed area, it is a trade line namely Petawangi (Peterongan Tawang - Siliwangi). Ahmad Yani airport also closes this area.

Brigjend Katamso area (Peterongan), Kaligawe area, and Setiabudi area (Banyumanik) area are alosa the density areas. Peterongan has access to Semarang Old City, Tanjung Mas harbor and trade area. Kaligawe is the alternative lines to small cities around Semarang, such as Demak; Kudus; Blora; and Pati. Terboyo bus station is located in this area. Setyabudi is crowded area; it is a gate of Semarang city.

\section{Methodology}

\subsection{Location}

The study is Kalibanteng area and Tugumuda area, which are the content of $\mathrm{CO}$ in the air are 20.610 and 17.175, above the tresshold. The roads are shown in table 4 and figure 1.

\subsection{Sample Characteristic}

Respondent lives or works around Bundaran Tugu Muda and Bundaran Kalibanteng by radius $500-1000$ metres. The sample size is 52 people, it is derived from Slovin formulas.

Most of respondent (46.2 percent) has income $\mathrm{Rp}$ 1.000.000,- to Rp 1.999.999,-- per month and only 9.62 percent has $R p 5.000 .000$,- to Rp 6.999.999,- per month. It indicates people are exposured by mobile source pollution has low income. Respondent age is about $21-30$ years old (35 percent) and education level is diploma/undergraduate (40 percent). It indicates the respondent is on productive age and has good enough education level.

\subsection{Contingent Valuation Method (CVM)}

People's awareness to keep their environment is valued by Contingent Valuation Method (CVM). CVM is a direct 
survey method on willingness to pay (WTP) and willingness to accept (WTA) of respondents. CVM has two benefit compared with inderect method. First, CVM can be used to count use value and non-use value on the same time. Secondly, the answer of WTP and WTA can be corrected directly on monetary in the level of change. (Lee, 1999 : 114).

The reseach model is :

$\mathrm{WTP}=\alpha_{0}+\alpha_{1} \mathrm{AGE}+\alpha_{2} \mathrm{INC}+\alpha_{3} \mathrm{EDUC}+\alpha_{5} \mathrm{CLUNGS}+\alpha_{6}$ $\mathrm{CEYES}+\alpha_{7} \mathrm{CNOSE}$

Where : WTP = willingness to pay to diminish mobile sources of pollution

$$
\begin{aligned}
& \text { INC = Income, per month } \\
& \text { EDUC = Education } \\
& \text { CLUNGS = Cost for lungs } \\
& \text { CEYES = Cost for eyes } \\
& \text { CNOSE = Cost for nose }
\end{aligned}
$$

\subsection{Analytical Hierarchy Process (AHP)}

AHP is function of hierarcy model and people's perception is an input (Saaty, 2008). AHP steps are:

a) Configure the problem hierarchy structure

It is shown on figure 1.

The goal is policy implication itself. It consists of four implications: (1) improvement in transportation infrastructure, (2) reforestation, (3) replacement of old motorized vehicles, and (4) the use of alternative roads on traffic peak hours.

b) Valuation on criteria and alternative

The criteria and alternative is valued by 1-9 scale, which is 9 is the best criteria

c) Configure the matrix

If the element is compared by own element, it is valued by
1. The result of comparing element $i$ with element $j$ is a number, and also the contrarary.

\section{Result}

\subsection{Health Cost}

Health cost is devided by three types: lungs cost, eyes cost, and nose cost.

a) 65 percent respondents willings to pay no more than Rp 50,000,- for lungs cost. 25 percent pays $\mathrm{Rp}$ 50.000 ,- to $\mathrm{Rp} 100.000$,- and only 10 percent pays more than Rp 100,000,-.

b) 40 percent respondent has WTP for cost for keeping their eyes no more $\mathrm{Rp} 15,000,-$. 44 percet willings to pay $R p 15,000,-$ to $R p 30,000$,- and only 15 percent pays more than $\operatorname{Rp} 30.000,-$.

c) Most of respondent has WTP for cost for keeping their nose no more Rp 15,000,- and and only 12 percent pays more than $\operatorname{Rp} 30.000,-$.

\subsection{Willingness to Pay (WTP)}

The determinant factors of the WTP are estimated by the ordered probit method. This model is applied on econometric model which has independent variable as ordinal multinomial-choice (Greene, 2000 : 875). It is diskrit choice which is applied to analyze data from Contingent Valuation survey. WTP respondent to diminish mobile sources of pollution in Semarang City was still low, 38 percent willings to pay no more than $\mathrm{Rp} 40,000$,- and 6 percent pays more than Rp 100,000,-. Table 5 showed the respondent's WTP.

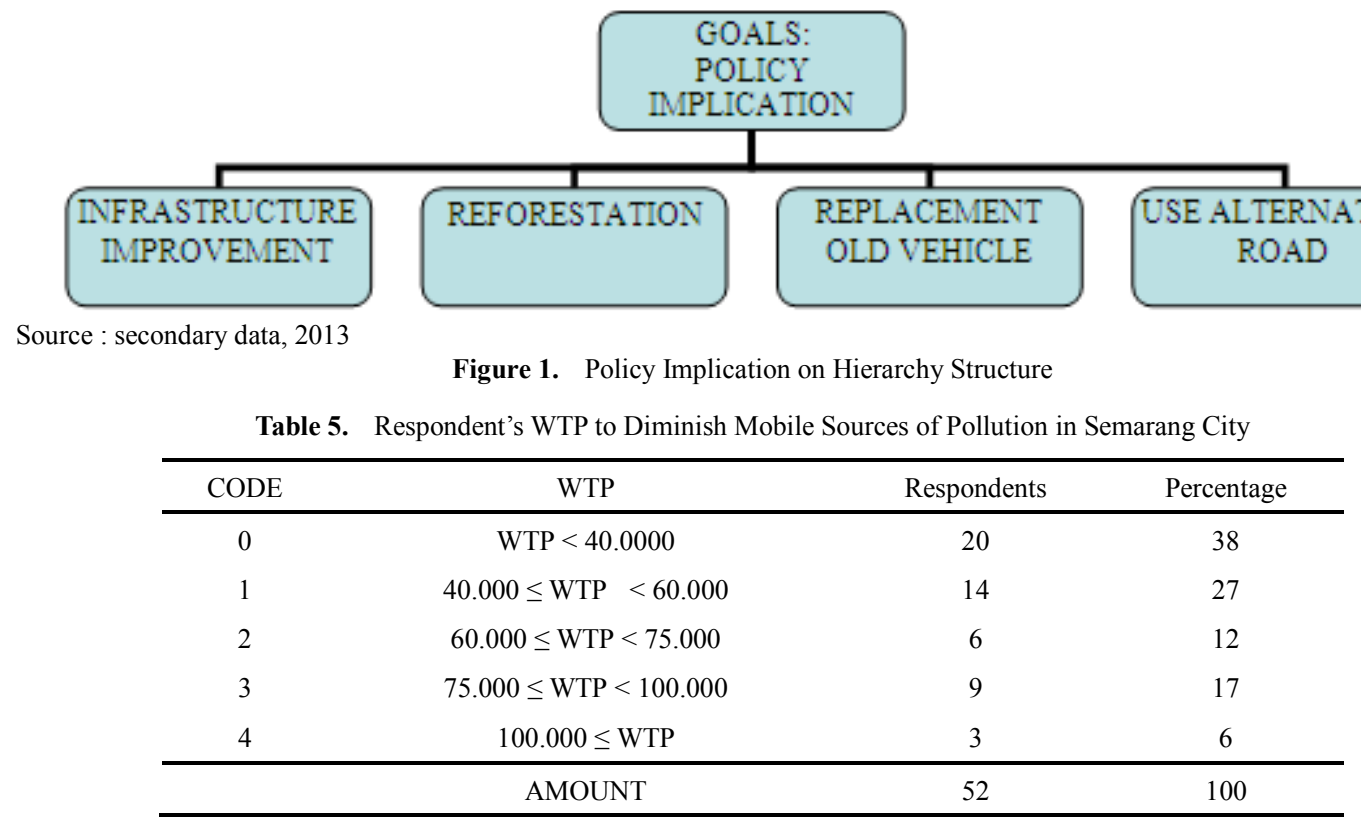

Source: primary data, 2014 
Table 6. Probability of WTP Respondent to Diminish Mobile Sources of Pollution in Semarang City

\begin{tabular}{ccc}
\hline Code & Group of WTP & Probability \\
\hline Prob $($ WTP $=0)$ & Prob (WTP $<$ Rp 40.000,-) & 0,5080 \\
Prob $($ WTP $=1)$ & Prob (Rp 40.000,- $\leq$ WTP $<$ Rp 60.000,-) & 0,2406 \\
Prob $($ WTP $=2)$ & Prob (Rp 60.000,- $\leq$ WTP $<$ Rp 75.000,-) & 0,1091 \\
Prob $($ WTP $=3)$ & Prob (Rp 75.000,- $\leq$ WTP $<$ Rp 100.000,-) & 0,1142 \\
Prob (WTP $=4)$ & Prob (WTP $\geq$ Rp 100.000,-) & 0,0281 \\
\hline
\end{tabular}

Source: Primary data, 2014

Table 7. Rank of Respondent Choice Preference

\begin{tabular}{cccccccc}
\hline CHOICES & $(1)$ & $(2)$ & $(3)$ & $(4)$ & Amount & Percentage & RANK \\
\hline$(1)$ & 0,36 & 0,45 & 0,35 & 0,44 & 1,60 & 40 & 1 \\
$(2)$ & 0,21 & 0,20 & 0,35 & 0,15 & 0,91 & 23 & 2 \\
$(3)$ & 0,26 & 0,16 & 0,17 & 0,26 & 0,85 & 21 & 3 \\
$(4)$ & 0,17 & 0,20 & 0,13 & 0,15 & 0,64 & 16 & 4 \\
\hline Amount & 1 & 1 & 1 & 1 & 4 & 100 & \\
\hline
\end{tabular}

Source : primary data, 2014

Probability of WTP respondent who pays no more than Rp 40,000 ,- is 50.80 percent and pays more than $\operatorname{Rp} 100,000$,- is only 2.81 percent. It is shown on table 6 .

The estimated results showed that the income of the respondents compared to health costs, caused by damaged lungs, eyes, and nose, has an influence on the WTP. While the age, education, and distance to the polluted area of the respondents are not significantly influencing the WTP.

\subsection{Preference of Importance Level of Policy Strategy}

Four alternative choices are offered to respondent to diminish mobile sources of pollution in Semarang City. There are: (1) improvement in transportation infrastructure, (2) reforestation, (3) replacement of old motorized vehicles, and (4) the use of alternative roads on traffic peak hours. These policies are doing in four years successively as respondent choice preference. Analytical Hierarchy Process (AHP) is used to estimate the level of respondent choice preference. Table 7 showed the rank of respondent choice preference as a result of AHP.

First rank of respondent choice preference on policy implication to diminish mobile sources of pollution in Semarang City is the improvement in transportation infrastructure. This policy is promised to reduce traffic density and air pollution. It will give positive impact to human health, especially on lung cost. The second rank is reforestation. Respondent willing's to pay to plant the tree. It has positive impact to make a better environment condition.

Some people are not willing to pay for replacement of old motorized vehicles as the third rank of respondent choice. They are low income respondent, such as a public transport driver. The reasons are they do not have enough money to replace the old machine and responsibility to pay the maintenance cost.

Using the alternative roads on traffic peak hours is the forth rank. The low of WTP respondent because they pessimistic of roads condition in Semarang City, such as vulnerable of flood; range of hill; and crowed area.

\section{Conclusion}

1. People's WTP to to diminish mobile sources of pollution in Semarang City was still low, 38 percent willing's to pay no more than Rp 40,000,- and 6 percent pays more than $\mathrm{Rp} 100,000,-$. It also showed on probability of respondent's WTP who pays no more than $\mathrm{Rp} 40,000$,- is 50.80 percent and pays more than $\mathrm{Rp} 100,000$,- is only 2.81 percent.

2. The estimated results showed that the income of the respondents compared to health costs, caused by damaged lungs, eyes, and nose, has an influence on the WTP. While the age, education, and distance to the polluted area of the respondents are not significantly influencing the WTP.

3. Four alternative choices are offered to respondent to diminish mobile sources of pollution in Semarang City. There are: (1) improvement in transportation infrastructure, (2) reforestation, (3) replacement of old motorized vehicles, and (4) the use of alternative roads on traffic peak hours.

\section{Policy Implication}

1. Campaign on diminishing mobile sources of pollution is needed by community to develop their awareness on the environmental condition.

2. Environmental education for kids and also adult is the important things to do. Policies implication can be running well if they have community support. 


\section{REFERENCES}

[1] Arianto A. Patunru. 2004. Valuasi Ekonomi: Stated-Preference Methods. Jakarta: LPEM - FEUI

[2] Bennet, J. 2008.Valuation Tools in Environmental Economics. Thailand: EEPSEA Modul

[3] Campbell, B. 1993.Monetary Valuation of Tree-Based Resources in Zimbabwe. Zimbabwe: Fao Corporate Document Repository

[4] David M. Cutler. 2009. Measuring National Well Being. Inggris: EconPapers

[5] Denny Borsboom, Gideon J. Mellenbergh, And Jaap Van Heerden. 1997. The Theoretical Status Of Latent Variables Economic Analysis of Selected Issues. Washington, D.C. World Bank

[6] Eugene D. Hahn, Refik Soyer. 2005. Probit And Logit Models: Differences In The Multivariate Realm. Amerika: Production

[7] Evans, W.N. 1999.Ordered Probit http://www.bsos.umd.edu/econ/evans

[8] Field, Barry C \& Martha K. 2006. Environmental Economics. Fourth Edition. Singapore: Mc Graw Hill

[9] Greene, W.H. 1991.Econometric Analysis, MacMillan Publishing Company. New York. Macmillan Publishing Company

[10] Jerry A. Hausman, A. Craig Mackinlay.1991.An Ordered Probit Analysis Of Transaction Prices. Amerika: Ideas
[11] Kim Vincent. 2014. Probit Analysis. Inggris: Youscribe

[12] Neil A. Powe And Kenneth G. Willis. 2002.Mortality And Morbidity Benefits Of Air Pollution Absorption By Woodland. Inggris: Deepdyve

[13] Nugroho, Sudarmanto Budi And Fujiwara. 2010. Akimasa. Private Motorized Urban Mobility And Its Impact On Inspection And Maintenance Program In Indonesia. Jakarta: .Journal Of Society For Transportation And Traffic Studies (Jsts)

[14] Ostro, B. 1992. Estimating the Health and Economic Effects of Particulate Matter in Jakarta: A Preliminary Assessment, Mexico: WHO

[15] Ostro, B., Eskeland, G.S., Aranda, C., and Sanchez, J.M. 1995. Air Pollution and Mortality : result from a Study of Santiago, Chile.Amerika: World Bank

[16] Ulrich Kaiser And Alexandra Spitz. 2000. Quantification Of Qualitative Data Using Ordered Probit Models With An Application To A Business Survey In The German Service Sector. Jerman: Econstor

[17] Saaty, T, L. 2008. The Analytic Hierarchy and Analytic Network Measurement Processes: Applications to Decisions under Risk. Eropa: European Journal of Pure and Applied Mathematics

[18] Soren Andersona, Richard G. Newellb. 2003. Simplified Marginal Effects In Discrete Choice Models. Amerika: Ideas

[19] Vassilis Markantonis. Kostas Bithas. The Application Of The Contingent Valuation Method In Estimating The Climate Change Mitigation And Adaptation Policies In Greece. An Expert Based Approach. Yunani: Proquest

[20] William Greene. 1998. Marginal Effects In The Censored Regression Model. New York: Ideas 